\title{
The Qu'ran Manuscripts in the al-Haram al-Sharif Islamic Museum, Jerusalem
}

\author{
Khader Salameh \\ Reading, UK: Garnet Publishing, 2001. 190 pages.
}

Founded in 1922 and moved to al-Haram al-Sharif in 1929, the Islamic Museum in Jerusalem houses artifacts covering nearly all of Islamic history and originating in North Africa, Turkey, Iran, Central Asia, and the Middle East.

This beautifully illustrated volume, published with the support of UNESCO in both English and Arabic, treats a small part of the Museum's collection: a selection of its Qur'an manuscripts. The work, divided into three parts, first introduces the Islamic Museum and its collection, then provides background information concerning relevant textual and art history, and finally presents 31 Qur'an manuscripts in detail.

Part One, "The Islamic Museum," gives an overview of the Museum's holdings, including wood, metalwork, ceramics, glass, textiles, coins, stone inscriptions and architectural elements, and documents. Most of the artifacts are material salvaged from repairs to the haram area or objects from the endowments of the Aqsa mosque and madrasahs in Jerusalem, Nablus, and Hebron. The collection includes many exquisite pieces: Umayyad floral woodwork panels from the al-Aqsa Mosque, a striking glass mosque lamp of the Mamluk amir Tankiz from Hebron, and the salvaged remains of Nur al-Din's pulpit, built in Aleppo in 564/1168 and brought to the Aqsa Mosque in 583/1187 by Salah al-Din after his conquest of Jerusalem. (Unfortunately, the ornate wooden pulpit was nearly destroyed by arson in 1969.)

Part Two, "Background," treats Arabic calligraphy, illumination, bindings, and the textual history of the Qur'an. Kufic, an old, square script said to derive from stone inscriptions, is used for the text of the oldest Qur'an manuscript in the collection and for headings and panels in later manuscripts.

The bulk of the manuscripts are written in the more cursive Naskhi script, which became popular by the tenth century, and the similar but taller Thuluth and Muhaqqaq. A number of the collections manscripts from North Africa are written in Maghribi script, which derives from Kufic and differs significantly from the common eastern scripts. This volume allows the reader to view some stunning examples of illumination, 
including decorative calligraphy, floral and geometric designs, and gilded and polychrome decorative panels. The examples show a wide variety of styles, ranging from rather simple black calligraphy in surah headings, to gold, blue, red, green, and orange displays of color from the Saljuq and Mamluk periods, to ornate leaves, carnations, tulips, vines, and pomegranates from the Ottoman period. The covers and containers for the Qur' ans were also quite ornate. Covers were most often leather, embossed and decorated, but some were silk, such as the blue and pistachio covered Qur'ans Salah al-Din sent as a gift to Nur al-Din.

Salameh's short summary of the textual history of the Qur'an, which draws on well-known sources, is adequate for an appreciation of the manuscripts discussed. The Islamic Museum holds 266 Qur'an manuscripts all together, two-thirds of which date from the Ottoman period and onethird from earlier periods.

Salameh has selected 12 single-volume Qur'ans (mushafs) and 19 multi-volume Qur'ans (rab ahs) for variety of period and calligraphic style to present in Part Three, "The Qur'an Manuscripts." The earliest manuscript in the collection, containing the second half of the Qur'an, dates from the third/ninth century. It is illuminated in gold, red, and green, with gold predominating; opening pages and surah headings consist of intertwined bands filled with colored spots in geometric patters, giving a mosaic effect. Written entirely in Kufic script, the manuscript is the only one in the collection to use the old system of red dots for vowel markings: above the letter for fathah (-a), below the letter for kasrah (-i), and level with the letter for dammah (-u).

Some interesting variants appear, such as ta-hi for ta-ha at Qur'an 20:1. Verse ends are marked with three small diagonal strokes (//I), whereas later manuscripts show round, floral, or asterisk-shaped marks. The mushaf of the fourteenth-century Marinid Sultan Abu al-Hasan is a fascinating display of devotion and presumably religio-political propaganda as well. This ruler, whose dynasty inherited power in Morocco and al-Andalus from the Almohads, wrote in his own hand three 30-volume rab 'ahs of the Qur'an, which he then had lavishly illuminated, bound, and set in decorative boxes. From his seat in Fez, he had them delivered to al-Haram al-Sharif in Makkah, the Prophet's Mosque in Madinah, and the Aqsa Mosque in Jerusalem. He must have done this not only to garner support at home but also to claim ascendancy among contemporary Muslim rulers; certainly, his Qur'ans impressed the Mamluks in the East. The rab 'ah sent to Jerusalem, completed in $745 / 1344$, was stored in a stunning leather-covered wooden 
box inlaid with sumptuous ornaments of silver and enamel. Also discussed are four rab ahs of the Ottoman ruler, Sultan Suleiman the Magnificent (1520-66), one from his son Bayezid, and many others.

These manuscripts shed considerable light on the liturgical use of the Qur'an. Many of the Qur'ans in the collection include endowment deeds recorded on the opening pages, stating who donated the manuscript, to which institution. Also assigned to many Qur'ans were perpetual endowments - the income of a bathhouse, for example - to pay stipends for scholars to recite part of that Qur' an at a certain time of day. For example, a mushaf from the eighth/fourteenth century was endowed to the Ibrahimi Mosque in Hebron by a prominent judge Qadi Shams al-Din Musa ibn Qadi Taj al-Din al-Nasiri. The endowment requires a reader to recite, while facing the tomb of Abraham, one hizb (160 verses) of the Qur'an after the morning and afternoon prayers, then some ahadith, then the last three suwar, followed by Surat al-Fatihah and the beginning of Surat alBaqarah. The endowments of rab ahs - generally of 30 volumes, each containing one juz' (130 verses) of the Qur'an - provided stipends for 30 readers, each responsible for one juz', and for nazir al-rab`ah, a supervisor to oversee the readers and distribute the stipends.

Combining strikingly beautiful illustrations with fascinating glimpses into Islamic art, patronage, and the liturgical, social, and political uses of the Qur'an, Salameh's book is a rewarding read.

Devin Stewart, Chair

Department of Middle Eastern and South Asian Studies

Emory University, Atlanta, Georgia 